\title{
ANALISIS EFEKTIVITAS PENGGUNAAN MICROPILE SEBAGAI ELEMEN PERKUATAN STABILITAS LERENG
}

\author{
Farrell Arman' dan Chaidir Anwar Makarim² \\ ${ }^{1}$ Program Studi Sarjana Teknik Sipil, Universitas Tarumanagara, Jl. Letjen S. Parman No.1 Jakarta \\ farrellarman@gmail.com \\ ${ }^{2}$ Program Studi Sarjana Teknik Sipil, Universitas Tarumanagara, Jl. Letjen S. Parman No.1 Jakarta \\ chaidir259@gmail.com
}

Masuk: 15-01-2020, revisi: 16-02-2020, diterima untuk diterbitkan: 17-02-2020

\begin{abstract}
Landslide is one of the most common problems in geotechnical field, especially in Indonesia. Landslide can occur due to increased shear stress or decreased shear strength of a soil mass. Basically, the shear strength of a soil mass is not able to withstand the load of the soil mass on top of it because the soil is unstable. To prevent landslides, an effective reinforcement is needed. Micropile is one of the options for reinforcement, it can retain soil mass, so the slope won't collapse on its own. Micropile can be used as a retaining wall, easy to be applied on the field, has a small diameter, and a relatively low cost. The compressive strength is used to withstand the soil mass. In this analysis, the micropile's strength will be analysed manually. The strength will then be reanalyzed with the help of a software. The result at the end of this process is the safety factor of the simulated slope. This analysis is done twice, with a reinforced slope and a slope without reinforcement, then both will be compared to one another. This analysis will then result in the effectiveness of micropile as an element to maintain slope stability.
\end{abstract}

Keywords: reinforcement; slope stability; micropile; safety factor; effectivity.

\begin{abstract}
ABSTRAK
Kelongsoran tanah pada lereng merupakan salah satu permasalahan yang paling sering terjadi di dalam dunia geoteknik, terutama di Indonesia. Kelongsorsan dapat terjadi akibat meningkatnya tegangan geser suatu massa tanah atau menurunnya kekuatan geser suatu massa tanah. Dengan kata lain, kekuatan geser dari suatu massa tanah tidak mampu memikul beban yang terdapat di atasnya karena kondisi tanah tidak stabil. Untuk mengatasi masalah kelongsoran pada lereng, diperlukan perkuatan yang tepat dan efektif. Micropile merupakan salah satu jenis perkuatan yang dapat membantu menahan massa tanah di lokasi yang lebih tinggi pada suatu lereng, karena micropile dapat dimanfaatkan sebagai dinding penahan tanah, mudah diaplikasikan, memiliki ukuran yang kecil, dan biaya yang relatif murah. Kapasitas micropile yang berguna untuk menahan massa tanah di lokasi yang lebih tinggi adalah kapasitas micropile untuk menahan tekan. Pada analisis ini, perhitungan kapasitas micropile akan dianalisa dengan perhitungan manual. Nilai kapasitas micropile kemudian akan diolah kembali dengan bantuan program metode kesetimbangan batas, sehingga didapatkan nilai faktor keamanan dari lereng yang telah didesain. Hasil pengolahan data dari analisis stabilitas lereng dengan micropile ini nantinya akan dibandingkan dengan hasil pengolahan data dari analisis stabilitas lereng tanpa micropile. Analisis ini akan menghasilkan efektivitas micropile sebagai elemen perkuatan stabilitas lereng.
\end{abstract}

Kata kunci: perkuatan; stabilitas lereng; micropile; faktor keamanan; efektivitas.

\section{PENDAHULUAN}

Seiring berkembangnya pembangunan di Indonesia, permasalahan di lingkup geoteknik semakin banyak dan beragam, dan hal ini diikuti dengan perkembangan metode-metode yang terus dipakai dan diperbaiki guna ,mendapatkan hasil analisis yang lebih baik dari sebelumnya. Salah satu analisis dalam lingkup geoteknik di Indonesia yang terus berkembang adalah analisis stabilitas atau perkuatan lereng.

Indonesia sendiri memiliki kondisi geologis dan geografis yang beragam, termasuk banyaknya daerah perbukitan dan lereng. Kondisi yang beragam tersebut membuat daerah lereng dan berbukit banyak dimanfaatkan sebagai tempat tinggal dan usaha guna mendapatkan efektivitas penggunaan lahan. Tetapi, masih ada saja kondisi tanah dan lereng yang tidak stabil ,sehingga berpotensi terjadinya kegagalan pada lereng tersebut. 
Salah satu upaya untuk mencegah terjadinya kegagalan tersebut perlu adanya perkuatan lereng dengan menggunakan dinding penahan tanah sistem stabilisasi internal, yang merupakan sistem memperkuat tanah untuk mencapai kestabilan yang dibutuhkan.

Adapun batasan masalah dalam penelitian ini adalah sebagai berikut: tidak memperhitungkan defleksi micropile, tidak memperhitungkan adanya beban gempa, tidak memperhitungkan penurunan tanah, tidak menganalisa efek korosi pada micropile, tidak memperhitungkan negative skin effect/ downdrag, dan aturan perhitungan mengacu pada Micropile Design and Construction (Federal Highway Administration 2005).

Tujuan dari penelitian ini yang pertama adalah untuk mengetahui seberapa signifikan nilai faktor aman yang dihasilkan dengan penggunaan micropile sebagai perkuatan stabilitas lereng dibandingkan dengan analisa stabilitas lereng tanpa menggunakan micropile, dan yang kedua adalah untuk mengetahui apakah ada efek dari penambahan jumlah penempatan posisi micropile yang bervariasi terhadap faktor aman lereng.

\section{Stabilitas lereng}

Lereng adalah permukaan bumi yang membentuk sudut kemiringan tertentu dengan bidang horizontal Lereng dapat terbentuk secara alamiah karena proses geologi ataukarena dibuat oleh manusia. Lereng yang terbentuk secara alamiah misalnya lereng bukit dan tebing sungai, sedangkan lereng buatan manusia antara lain yaitu galian dan timbunan untuk membuat jalan raya dan jalan kereta api, bendungan, tanggul sungai dan kanal serta tambang terbuka.

Suatu longsoran adalah keruntuhan dari massa tanah yang terletak pada sebuahlereng sehingga terjadi pergerakan massa tanah ke bawah dan ke luar. Longsoran dapat terjadi dengan berbagai cara, secara perlahan-lahan atau mendadak serta denganataupun tanpa tanda-tanda yang terlihat.

Tanpa sebuah model geologi yang memadai, analisis hanya dapat dilakukan dengan menggunakan pendekatan yang kasar sehingga kegunaan dari hasil analisis dapat dipertanyakan.Beberapa pendekatan yang dapat dilakukan adalah dengan menggunakan metode-metode seperti : metode Taylor, metode janbu, metode Fenellius, metode Bishop, dan lain-lain

Dalam skripsi Edwindhi Nurmanza yang berjudul "Analisis Stabilitas Lereng Dengan Perkuatan Tiang (Pile) Dengan Bantuan Perangkat Lunak" pada tahun 2017, disebutkan bahwa untuk menentukan kestabilan atau kemantapan lereng dikenal istilah faktor keamanan (safety factor) yang merupakan perbandingan antara gaya-gaya yang menahan gerakan terhadap gaya-gaya yang menggerakkan tanah tersebut dianggap stabil, bila dirumuskan sebagai berikut :

$$
F=\tau / \tau_{d}
$$

dengan $\mathrm{F}=$ Faktor Aman, $\tau=$ Tahanan Geser Maksimum Yang Dapat Dikerahkan Oleh Tanah,$\tau_{d}=$ Tegangan Geser Yang Terjadi Akibat Gaya Berat Tanah Yang Akan Longsor.

Dimana menurut Bowles (1989) ,untuk keadaan:

- $\mathrm{F}>1,5$ : lereng dalam keadaan mantap

- $\mathrm{F}=1,5$ : lereng dalam keadaan seimbnag, dan siap untuk longsor

- $\mathrm{F}<1,5$ : lereng tidak mantap

Mohr - Coulomb, tahanan geser $(\tau)$ yang dapat dikerahkan tanah sepanjang bidang longsornya dinyatakan:

$$
\tau=c+\sigma \operatorname{tg} \varphi
$$

dengan $\mathrm{c}=$ Kohesi Tanah, $\varnothing=$ Sudut Gesek Tanah

Persamaan geser yang terjadi akibat beban tanah dan beban lain pada bidang longsornya.

dengan $\mathrm{c}_{d}=$ Kohesi Tanah, $\varnothing_{d}=$ Sudut Gesek Tanah

$$
\tau_{d}=c_{d}+\sigma \operatorname{tg} \varphi_{d}
$$

Dalam esai berjudul Stability Analysis of Pile-Slope System yang ditulis oleh Seyhat Firan pada tahun 2009, disebutkan bahwa perhitungan stabilitas lereng dilakukan dengan menggunakan metode Bishop dengan bantuan program, pada metode Bishop yang disederhanakan, software ini terlebih dahulu menggunakan rumus Ordinary atau metode Fellinius. 


$$
F S f=\frac{\sum\left[c^{\prime} \cdot b i+N \tan \emptyset\right.}{\sum[W \sin \alpha i]}
$$

dengan FSf $=$ Faktor aman lereng Fellinius, $c^{\prime}=$ Kohesi tanah efektif $\left(\mathrm{kN} / \mathrm{m}^{2}\right), \emptyset^{\prime}=$ Sudut gesek dalam tanah efektif (derajat), b' = Lebar irisan ke-i $(\mathrm{m}), \mathrm{Wi}=$ Berat irisan tanah ke-i $(\mathrm{kN}), \mathrm{I}=$ Sudut yang didefinisikan pada lereng (derajat).

\section{Micropile}

Micropile adalah tiang yang memiliki diameter kecil (lebih kecil dari $300 \mathrm{~mm}$ ), yang dikonstruksi dengan cara mengebor tanah lalu diinjeksi dengan semen kemudian diperkuat menggunakan tulangan seperti diilustrasikan pada Gambar 1. Micropile dapat menahan beban vertikal, lateral, dan bisa dipertimbangkan sebagai pengganti fondasi atau memperkuat fondasi yang sudah ada bergantung pada desain rencana.

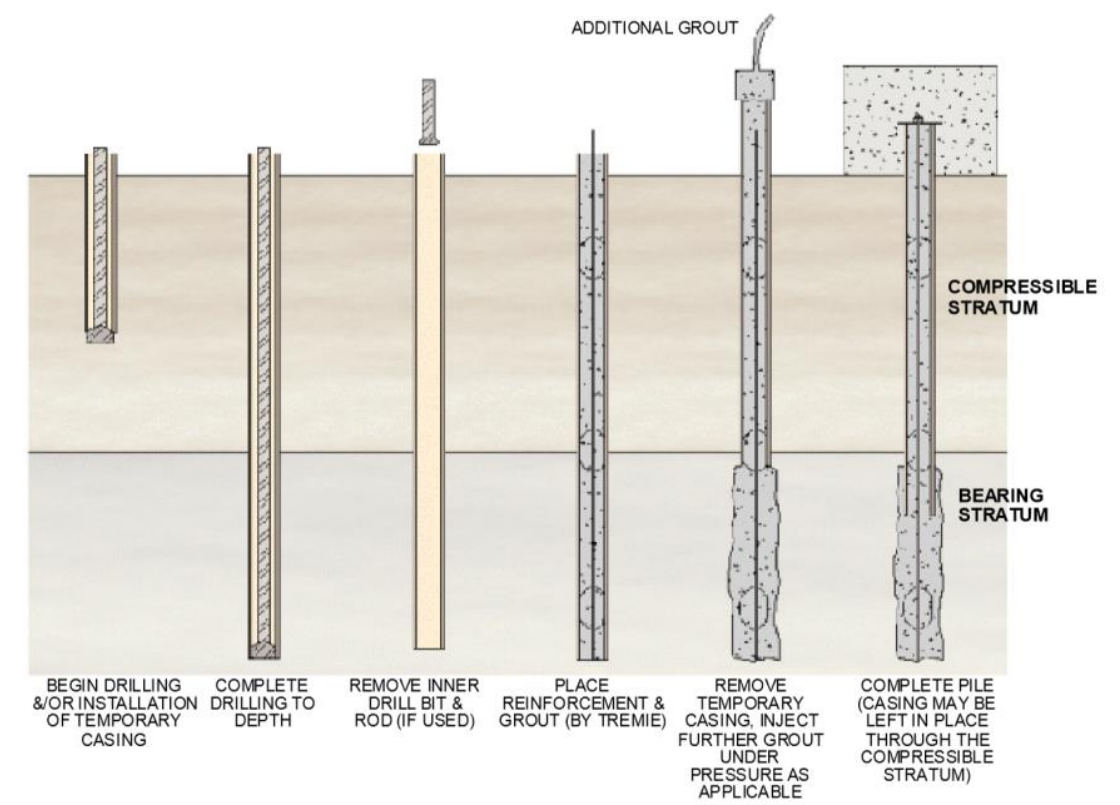

Gambar 1. Ilustrasi urutan konstruksi micropile

Analisis kapasitas dukung micropile menggunakan persamaan yang dirumuskan oleh Federal Highway Administration (FHWA). Kapasitas dukung micropile terbagi atas allowable compression load for cased length, allowable tension load for cased length, allowable compression load for uncased length, allowable tension load for uncased length.

Allowable compression load for cased length menggunakan persamaan:

$$
P_{c-\text { allowable }}=\left[0.4 f^{\prime}{ }_{c \text {-grout }} \times A_{\text {grout }}+0.47 F_{y-\text { steel }}\left(A_{\text {bar }}+A_{\text {casing }}\right)\right]
$$

Allowable tension load for cased length menggunakan persamaan:

$$
P_{t-\text { allowable }}=\left[0.55 F_{y \text {-steel }} \times\left(A_{\text {bar }}+A_{\text {casing }}\right)\right]
$$

Allowable compression load for uncased length menggunakan persamaan:

$$
P_{c-\text { allowable }}=\left[0.4 f_{c-\text { grout }}^{\prime} \times A_{\text {grout }}+0.47 F_{y-\text { steel }} \times A_{\text {bar }}\right]
$$

Allowable tension load for uncased length menggunakan persamaan:

$$
P_{t-\text { allowable }}=\left[0.55 F_{y \text {-steel }} x\left(A_{\text {bar }}+A_{\text {casing }}\right)\right]
$$

dengan $P_{c \text {-allowable }}=$ Gaya tekan yang diijinkan $(\mathrm{N}), f_{c \text {-grout }}=$ Kuat tekan beton $(\mathrm{MPa}), A_{\text {grout }}=$ Luas area beton $\left(\mathrm{m}^{2}\right), F_{y-s t e e l}=$ Tegangan leleh baja $(\mathrm{MPa}), A_{\text {bar }}=$ Luas area tulangan $\left(\mathrm{m}^{2}\right), A_{\text {casing }}=$ Luas area casing $\left(\mathrm{m}^{2}\right)$. 


\section{METODOLOGI PENELITIAN}

\section{Metode pengumpulan data}

Metode yang digunakan untuk pengumpulan data penelitian ini adalah teknik dokumentasi yaitu pengumpulan data dari proyek sebagai acuan profil tanah yang akan digunakan untuk desain lereng. Pada penelitian ini, data tanah yang dianalisis berlokasi pada Pulau Jawa. Pada penelitian ini digunakan metode literatur yang berdasarkan buku dan jurnal yang sudah ada.

\section{Metode analisis data}

Sebelum dilakukannya analisis, dilakukan studi literatur dengan mencari dasar-dasar teori dan sumber data seperti jurnal, buku referensi untuk mendapatkan rumus-rumus dalam menghitung daya dukung micropile dan besarnya tekanan pengembangan. Metode analisis yang digunakan untuk menghitung kapasitas dukung micropile yaitu menggunakan perhitungan manual yang mengacu pada FHWA (Federal Highway Administration). Metode analisis yang digunakan untuk menghitung besarnya factor of safety yaitu menggunakan perhitungan dengan bantuan program dengan metode kesetimbangan batas yang mengacu pada metode Bishop. Analisis akan dilakukan pada kondisi lereng tanpa menggunakan micropile dan juga pada kondisi lereng setelah menggunakan micropile, sehingga hasil dari kedua kondisi tersebut dapat dibandingkan dan kemudian dapat disimpulkan seberapa efektif penggunaan micropile sebagai elemen perkuatan pada stabilitas lereng.

\section{HASIL DAN PEMBAHASAN}

\section{Korelasi Data Tanah}

Analisis penelitian ini berdasarkan data tanah yang diperoleh dari suatu tanah di pulau jawa dan dikorelasi, seperti pada tabel 1 berikut.

Tabel 1. Hasil data tanah korelasi

\begin{tabular}{|c|c|c|c|c|c|c|}
\hline Depth (m) & $\Delta(\mathrm{m})$ & N-SPT & $\mathrm{c}\left(\mathrm{KN} / \mathrm{m}^{2}\right)$ & $\phi\left({ }^{0}\right)$ & $\Upsilon^{\prime}\left(\mathrm{KN} / \mathrm{m}^{2}\right)$ & $\mathrm{Qu}(\mathrm{kPa})$ \\
\hline 0 & 4 & 3 & 24.00 & 15.04 & 14.60 & 37.5 \\
\hline 4 & 4 & 10 & 46.00 & 21.40 & 17.20 & 130 \\
\hline 8 & 4 & 48 & 21.00 & 37.00 & 20 & 400 \\
\hline 12 & 4 & 35 & 174.00 & 32.50 & 20 & 400 \\
\hline 16 & 4 & 42 & 210.00 & 34.00 & 20 & 400 \\
\hline 20 & 4 & 35 & 174.00 & 32.50 & 20 & 400 \\
\hline & 4 & 20 & 57.00 & 25.32 & 19.80 & 267 \\
\hline & 8 & 18 & 53.00 & 23.00 & 18.70 & 240 \\
\hline & 8 & 25 & 62.00 & 27.21 & 20 & 335 \\
\hline 40 & 2 & 21 & 55.00 & 27.00 & 19.20 & 280 \\
\hline
\end{tabular}

\section{Kapasitas dukung micropile}

Berikut merupakan spesifikasi micropile yang digunakan untuk analisis kapasitas micropile yaitu
1. $\mathrm{f}^{\prime}{ }_{\mathrm{c}}$
$=25 \mathrm{MPa}$
2. $\mathrm{f}_{\mathrm{y}}$ casing
$=235 \mathrm{MPa}$
3. $\mathrm{f}_{\mathrm{y}}$ bar
$=400 \mathrm{MPa}$
4. Diameter luar (OD)
$=165.2 \mathrm{~mm}$
5. $\mathrm{t}_{\mathrm{w}}$
$=6 \quad \mathrm{~mm}$
6. D $\mathrm{D}_{\text {tulangan }}$
$=13 \mathrm{~mm}$
7. Diameter bor
$=200 \mathrm{~mm}$ 
Berdasarkan Spesifikasi yang dipakai tersebut setelah dilakukan analisis data, didapati nilai kapasitas dukung vertikal sebagai berikut. Pada bagian cased length micropile didapati bahwa nilai $\mathrm{P}_{\mathrm{c} \text {-allowable }}$ adalah sebesar 52.91 ton dan $\mathrm{P}_{\mathrm{t}-\text { allowable }}$ adalah sebesar 40.50 ton. Pada bagian uncased length micropile didapati bahwa nilai $\mathrm{P}_{\mathrm{c}-\text { allowable }}$ adalah sebesar 33.91 ton dan $\mathrm{P}_{\mathrm{t}-\text { allowable }}$ adalah sebesar 2.92 ton.

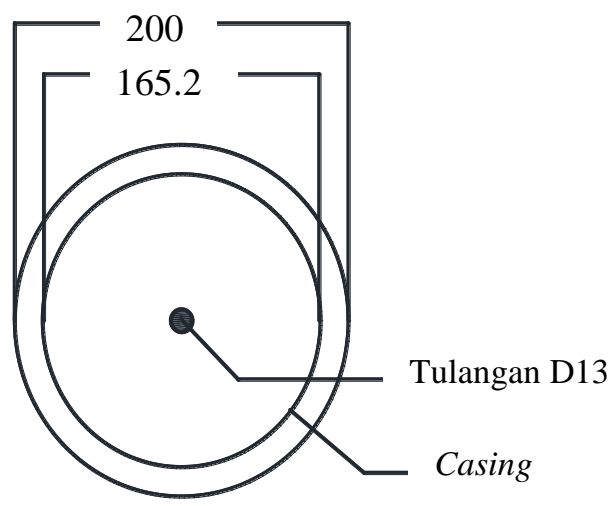

Gambar 2. Detail micropile

Setelah dilakukan analisis data, didapat kapasitas dukung horisontal seperti pada tabel 2 berikut.

Tabel 2. Kapasitas dukung horisontal micropile

\begin{tabular}{|c|c|c|c|c|c|c|c|}
\hline $\begin{array}{c}\text { Tipe } \\
\text { Penampang }\end{array}$ & $\begin{array}{c}\text { Modulus of } \\
\text { Elasticity } \\
\text { (MPa) }\end{array}$ & $\mathrm{f}^{\prime} \mathrm{c}(\mathrm{MPa})$ & $\mathrm{D}(\mathrm{m})$ & $\begin{array}{l}\text { General } \\
\text { Type Soil }\end{array}$ & $\mathrm{b}(\mathrm{m})$ & $\mathrm{q}_{\mathrm{u}}(\mathrm{kPa})$ & $\mathrm{c}_{\mathrm{u}}(\mathrm{kPa})$ \\
\hline \multirow{6}{*}{$\begin{array}{c}\text { OD } 165.2, \mathrm{tw} \\
6\end{array}$} & 200000 & 25 & 2.0 & \multirow{6}{*}{$\begin{array}{c}\text { Cohesive } \\
\text { Soil }\end{array}$} & 0.2 & 400 & 200 \\
\hline & 200000 & 25 & 3.0 & & 0.2 & 400 & 200 \\
\hline & 200000 & 25 & 4.0 & & 0.2 & 400 & 200 \\
\hline & 200000 & 25 & 6.0 & & 0.2 & 400 & 200 \\
\hline & 200000 & 25 & 8.0 & & 0.2 & 400 & 200 \\
\hline & 200000 & 25 & 10.0 & & 0.2 & 400 & 200 \\
\hline
\end{tabular}

Tabel 3. Kapasitas dukung horisontal micropile

\begin{tabular}{|c|c|c|c|c|c|c|c|}
\hline \multirow{2}{*}{$\begin{array}{c}\text { Tipe } \\
\text { Penampang }\end{array}$} & \multirow[b]{2}{*}{$\mathrm{n}_{1}$} & \multirow[b]{2}{*}{$\mathrm{n}_{2}$} & \multirow{2}{*}{$\begin{array}{c}\mathrm{K}_{\mathrm{h}} \\
\left(\mathrm{kN} / \mathrm{m}^{3}\right)\end{array}$} & \multirow{2}{*}{$\begin{array}{c}\mathrm{K}_{\mathrm{h}^{\prime}} \\
\left(\mathrm{kN} / \mathrm{m}^{3}\right)\end{array}$} & \multicolumn{3}{|c|}{ Properti Penampang } \\
\hline & & & & & $\begin{array}{c}\text { A casing } \\
\left(\mathrm{m}^{2}\right)\end{array}$ & $\begin{array}{c}\text { Inersia } \\
\text { casing }\left(\mathrm{m}^{4}\right) \\
\end{array}$ & $\begin{array}{c}\text { Section modulus } \\
\left(\mathrm{m}^{3}\right)\end{array}$ \\
\hline \multirow{6}{*}{$\begin{array}{l}\text { OD } 165.2 \\
\quad \text { tw } 6\end{array}$} & 0.36 & 1.15 & 66240 & 22080 & 0.00300 & 0.0001523 & 0.001844 \\
\hline & 0.36 & 1.15 & 66240 & 22080 & 0.00300 & 0.0001523 & 0.001844 \\
\hline & 0.36 & 1.15 & 66240 & 22080 & 0.00300 & 0.0001523 & 0.001844 \\
\hline & 0.36 & 1.15 & 66240 & 22080 & 0.00300 & 0.0001523 & 0.001844 \\
\hline & 0.36 & 1.15 & 66240 & 22080 & 0.00300 & 0.0001523 & 0.001844 \\
\hline & 0.36 & 1.15 & 66240 & 22080 & 0.00300 & 0.0001523 & 0.001844 \\
\hline
\end{tabular}


Tabel 4. Kapasitas dukung horisontal micropile

\begin{tabular}{|c|c|c|c|c|c|c|c|c|}
\hline \multirow{2}{*}{$\begin{array}{c}\text { Tipe } \\
\text { Penampang }\end{array}$} & \multirow{2}{*}{$\begin{array}{c}\text { My } \\
(\mathrm{kN}-\mathrm{m})\end{array}$} & \multirow{2}{*}{$\beta_{\mathrm{h}}$} & \multicolumn{2}{|c|}{ Kategori pile } & \multirow{2}{*}{$\mathrm{ec} / \mathrm{b}$} & \multirow{2}{*}{$\mathrm{My} / \mathrm{c}_{\mathrm{u}} \mathrm{b}^{3}$} & \multirow{2}{*}{$\mathrm{Q}_{\mathrm{u}} / \mathrm{c}_{\mathrm{u}} \mathrm{b}^{2}$} & \multirow{2}{*}{$\mathrm{Q}_{\mathrm{u}}(\mathrm{kN})$} \\
\hline & & & $\beta_{\mathrm{h}} * \mathrm{D}$ & Kategori & & & & \\
\hline \multirow{6}{*}{$\begin{array}{l}\text { OD } 165.2, \\
\quad \text { tw } 6\end{array}$} & 46.1 & 2.4535 & 4.907 & Panjang & \multirow{6}{*}{0} & 28.8125 & 11 & 35.2 \\
\hline & 46.1 & 2.4535 & 7.3605 & Panjang & & 28.8125 & 11 & 35.2 \\
\hline & 46.1 & 2.4535 & 9.814 & Panjang & & 28.8125 & 11 & 35.2 \\
\hline & 46.1 & 2.4535 & 14.721 & Panjang & & 28.8125 & 11 & 35.2 \\
\hline & 46.1 & 2.4535 & 19.628 & Panjang & & 28.8125 & 11 & 35.2 \\
\hline & 46.1 & 2.4535 & 24.535 & Panjang & & 28.8125 & 11 & 35.2 \\
\hline
\end{tabular}

Berdasarkan hasil perhitungan data dan analisis dengan bantuan program, perbandingan faktor aman dan juga peningkatannya yang dihasilkan dari 3 kondisi lereng disajikan pada tabel 3.

Tabel 5. Perbandingan factor of safety dari analisis lereng

\begin{tabular}{|c|c|}
\hline Kondisi Lereng & F of S \\
\hline 1 & 0,84 \\
\hline 2 & 1,102 \\
\hline 3 & 1,635 \\
\hline 4 & 1,602 \\
\hline
\end{tabular}

Keterangan:

Kondisi 1: Lereng tanpa menggunakan micropile

Kondisi 2: Lereng dengan menggunakan 1 micropile pada titik lereng atas

Kondisi 3: Lereng dengan menggunakan 2 micropile pada titik lereng atas dan tengah

Kondisi 4: Lereng dengan menggunakan 2 micropile pada titik lereng atas dan bawah

Kondisi-kondisi analisis desain lereng dengan konfigurasi micropile yang bervariasi akan ditunjukkan pada gambar 3 sampai dengan gambar 6 dibawah ini beserta dengan kondisi topografi dari tampak atas dan juga nilai Factor of Safety yang dihasilkan.

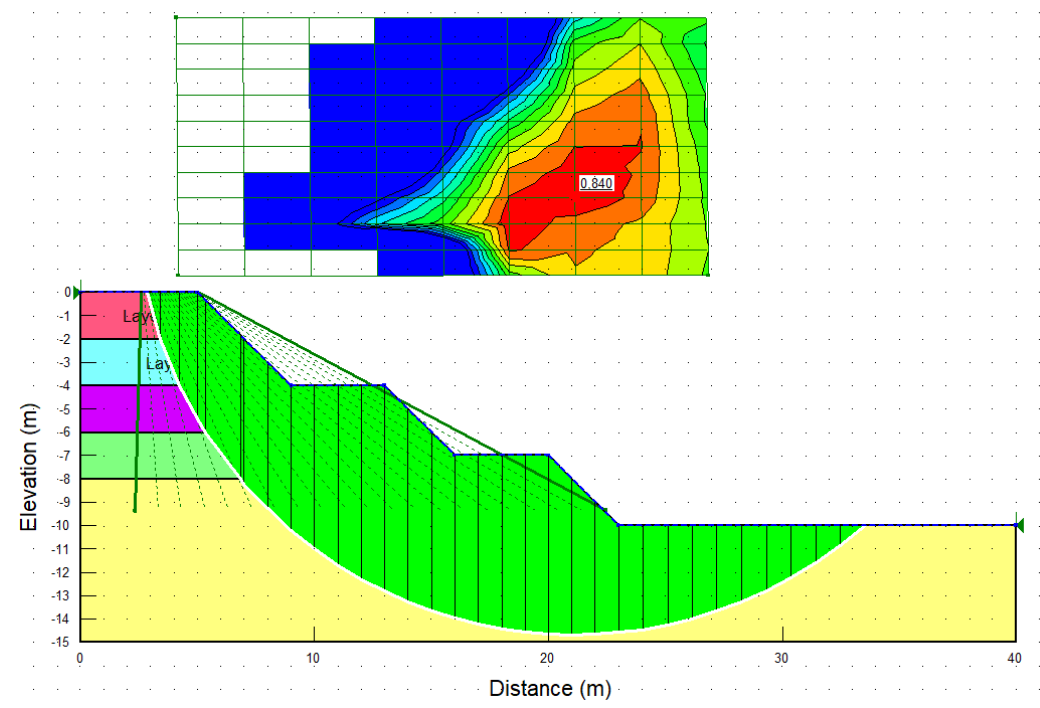

Gambar 3. Lereng kondisi 1 yaitu lereng tanpa menggunakan micropile 


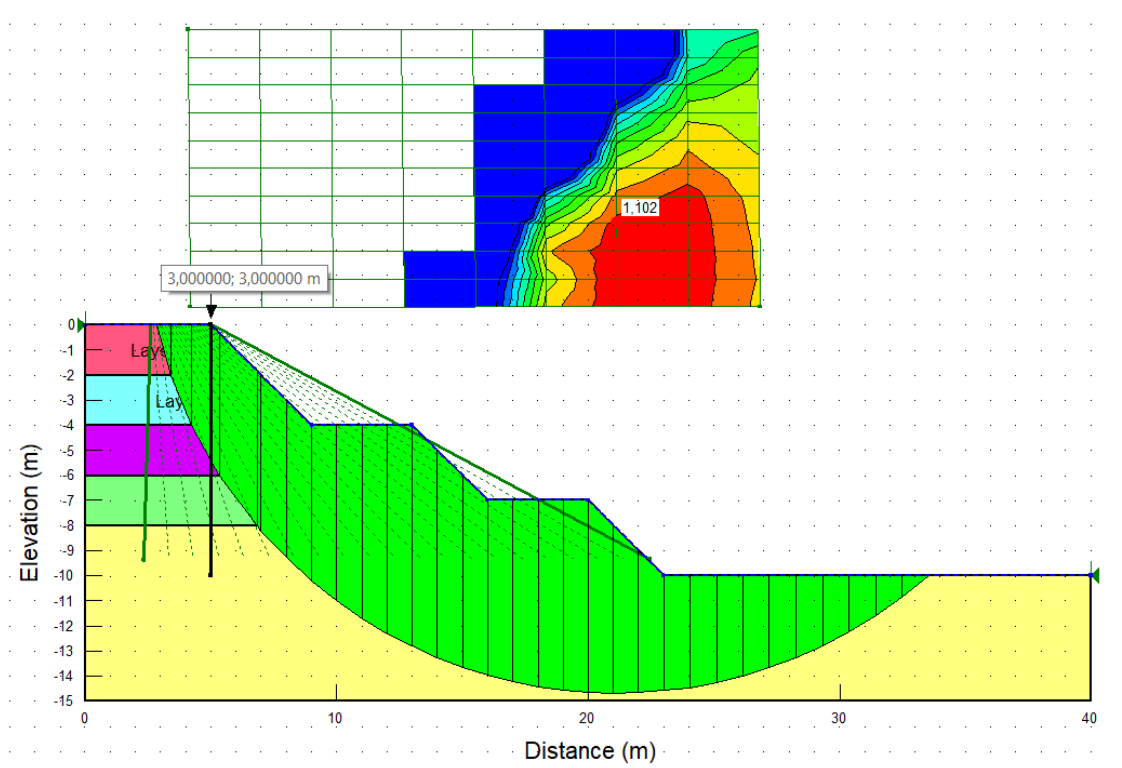

Gambar 4. Lereng kondisi 2 lereng dengan menggunakan 1 micropile pada titik lereng atas

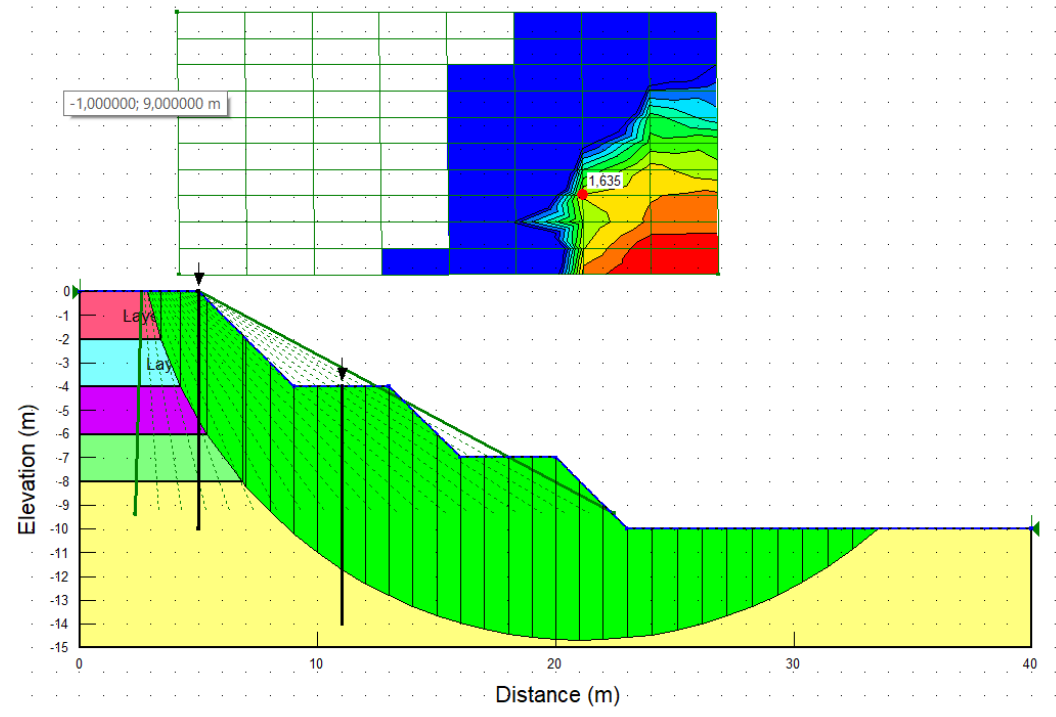

Gambar 5. Lereng kondisi 3 lereng dengan menggunakan 2 micropile pada titik lereng atas dan tengah 


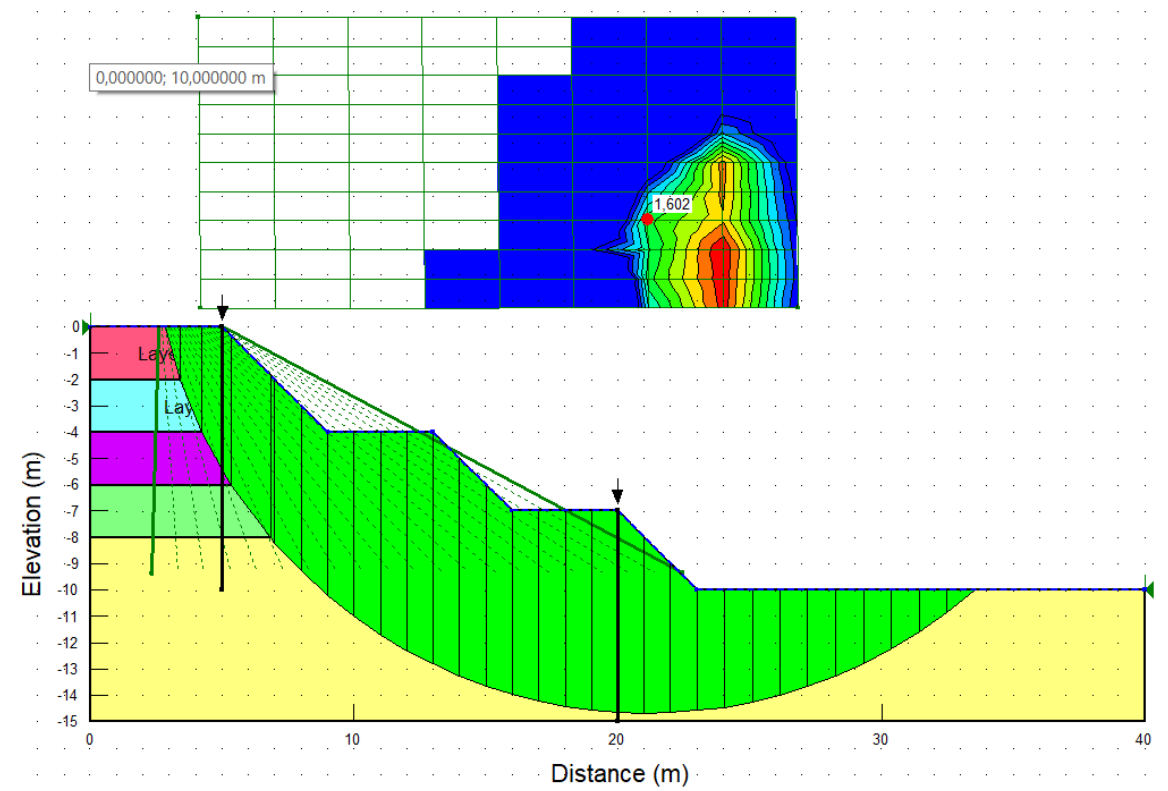

Gambar 6. Lereng kondisi 4 lereng dengan menggunakan 2 micropile pada titik lereng atas dan bawah

\section{KESIMPULAN DAN SARAN}

\section{Kesimpulan}

Dari hasil perhitungan kapasitas dukung micropile, penerapan micropile pada lereng, dan analisis stabilitas lereng, maka dapat ditarik kesimpulan sebagai berikut:

1. Berdasarkan hasil pengolahan data, didapati bahwa kapasitas tekan yang dihasilkan micropile untuk menopang beban vertikal yang ada diatasnya adalah sebesar 33.91 Ton untuk uncased length.

2. Berdasarkan hasil perhitungan, semua micropile masuk dalam kategori tiang panjang, karena semua micropile memiliki nilai $\beta_{\mathrm{h}} \mathrm{D}$ yang melebihi 2.25 , sehingga semua micropile yang dipakai memiliki Qu yang sama.

3. Berdasarkan hasil pengolahan data dan perhitungan, penambahan jumlah micropile dan juga variasi penempatan posisi micropile sebagai elemen perkuatan lereng menghasilkan perbedaan nilai faktor aman yang cukup kecil jika dilihat dari irisan lereng yang paling kritis, dimana desain lereng dengan penempatan micropile pada titik kontur dan sisi miring lereng menghasilkan nilai faktor aman yang lebih besar dibandingkan dengan desain lereng yang menggunakan micropile pada titik kontur saja.

4. Berdasarkan hasil analisa yang telah dilakukan, dapat disimpulkan bahwa pada desain lereng di penelitian ini, penggunaan 3 micropile pada titik-titik kontur yang telah ditentukan menghasilkan faktor aman dengan nilai di atas 1,5 pada seluruh irisan lereng, sehingga penambahan jumlah micropile dan variasi posisi micropile pada desain lereng tersebut tidak dibutuhkan.

5. Berdasarkan hasil perhitungan analisis stabilitas lereng dan setelah dilakukan perbandingan, lereng yang menggunakan micropile sebagai perkuatan menghasilkan faktor aman yang lebih tinggi secara signifikan dibandingkan dengan lereng yang tidak menggunakan micropile, shingga micropile relatif efektif untuk digunakan sebagai elemen perkuatan lereng.

\section{Saran}

Berikut merupakan saran yang diperlukan agar penelitian selanjutnya dapat dilakukan dengan lebih baik lagi, diharapkan ketersediaan data laboratorium yang lebih lengkap untuk menganalisis kondisi tanah di daerah sekitar lereng sehingga bisa didapatkan hasil yang lebih akurat dan sesuai dengan kondisi lapangan. Diharapkan juga dilakukannya analisis stabilitas lereng dengan micropile dengan metode lain untuk melengkapi kekurangan pada analisis skripsi ini, dimana pada analisis dengan program pada skripsi ini hanya menggunakan parameter tanah yang sederhana dan juga perhitungan micropile yang belum menyertai banyak faktor-faktor lain yang dapat mempengaruhi stabilitas lereng seperti beban vertikal di atas lereng, defleksi tiang, tekanan air pori, dan juga gempa, sehingga hasil yang didapatkan pada penelitian ini kurang akurat. 


\section{DAFTAR PUSTAKA}

Bowles, Sifat-sifat Fisik \& Geoteknis Tanah. Jakarta: Erlangga, 1989.

Federal Highway Administration, Micropile Design and Construction. Washington, D.C: Federal Highway Administration, 2005.

Federal Highway Administration, Design and Construction of Driven Pile Foundations-Volume I. Washington, D.C: Federal Highway Administration, 2006.

Firat, Seyhan, "Stability Analysis of Pile-Slope System”. Scientific Research and Essay, vol. 4, no. 9, 2009, pp. 842852.

Nurmanza, Edwindhi, Analisis Stabilitas Lereng Dengan Perkuatan Tiang (Pile) Dengan Bantuan Perangkat Lunak (Studi Kasus Pada Sungai Parit Raya). Malang: Universitas Brawijaya, 2017. 
Analisis Efektivitas Penggunaan Micropile

Farrell Arman, et al.

Sebagai Elemen Perkuatan Stabilitas Lereng 